\title{
OPEN Eclogite resembling metamorphic disequilibrium assemblage formed through fluid-induced metasomatic reactions
}

\author{
Sanghoon Kwon ${ }^{1}$, Vinod O. Samuel ${ }^{1 \bowtie}$, Yungoo Song ${ }^{1}$, Sung Won Kim² ${ }^{2}$ Seung-lk Park ${ }^{3}$, \\ Yirang Jang ${ }^{4} \&$ M. Santosh ${ }^{5,6}$
}

Equilibrium omphacite-garnet-bearing mafic rocks have been classified as eclogites, either pristine or retrogressed, that were formed at great depths in the lithosphere. Here we report a unique natural example of eclogite resembling assemblage in disequilibrium formed through fluid-induced metasomatic reactions under the amphibolite to granulite facies. Primarily, the amphibolized protolith experienced a garnet-amphibolite facies metamorphism at $\sim 500-700^{\circ} \mathrm{C}$ and $\sim 0.8-1 \mathrm{GPa}$. Subsequently, $\mathrm{CO}_{2}$ fluid induced fracturing and dissolution-reprecipitation reactions occurred at peak metamorphic conditions of $\sim 700^{\circ} \mathrm{C}$ and $\sim \mathrm{GPa}$. Occasional omphacite-albite assemblage, which gradually replace diopside-oligoclase symplectite adjacent to albite veins along fractures, indicates fluid-induced coupled dissolution-reprecipitation disequilibrium reactions. Here the albite-omphacite assemblage is in local equilibrium at least on $1 \mathrm{~mm}$ length scale, during cooling, below $\sim 600^{\circ} \mathrm{C}$ and $\sim \mathrm{GPa}$, within the amphibolite facies conditions. The results from this study clearly suggest that disequilibrium garnet-omphacite assemblage in mafic rocks could be formed by crustal reworking processes below granulite facies conditions, and their textural equilibrium is an important criterion while defining eclogite facies.

Eclogite facies metamorphic rocks formed through subduction and collision processes are common in global orogenic belts ${ }^{1-12}$ (e.g., Usagaran belt ${ }^{1}$, Belomorian Belt ${ }^{2}$, Trans-Hudson orogen ${ }^{3}$, Grenvillian-Caledonian belt ${ }^{4,5}$ Qinling-Dabie-Sulu belt ${ }^{6}$, Appalachian Orogenic Belt ${ }^{7}$, Central Asian Orogenic Belt ${ }^{8}$, Sambagawa belt ${ }^{9}$, AlpineHimalayan belt ${ }^{10,11}$, Franciscan complex ${ }^{12}$ etc.) created throughout Earth's history. Equilibrium omphacite-garnet assemblage along with other minor high-pressure phases (e.g., coesite, micro-diamonds) in such rocks are considered as evidence for their burial to mantle depths of about 150 to $200 \mathrm{~km}$, followed by exhumation to crustal levels ${ }^{13-15}$. In exhumed rocks, the relict phases and their trace element characteristics provide robust information on former deep burial of these rocks ${ }^{16,17}$.

Eclogites are metamorphosed mafic rocks that experienced high-pressure metamorphism, composed of garnet and omphacitic clinopyroxene with or without additional minor phases (e.g., phengite, lawsonite, kyanite, coesite, rutile etc.) formed at temperature $>500{ }^{\circ} \mathrm{C}$ and pressure $>1.2 \mathrm{GPa}^{18,19}$. The omphacite is a Na-pyroxene with $\mathrm{X}_{\text {Iadeite (Na) }}$ greater than 0.2 and less than $0.8^{20}$. This definition of eclogite suggests that garnet and omphacite, as major or relict minerals in rocks, could be an important indicator of previous deep burial of the crustal rocks. Experimental investigations suggest that gabbro/basalt to eclogite transformation is characterized by the formation of garnet-omphacite assemblage, where there is a gradual increase in the pyrope content of the garnet, and plagioclase is absent ${ }^{21}$. However, there are examples of different end members of garnet $(\mathrm{Fe}, \mathrm{Mg}$ or $\mathrm{Mn}$ ) equilibrated with omphacite in the presence or absence of plagioclase under high-pressure conditions in metamorphosed sodic trachyte, alkali olivine basalt and eclogitic schists ${ }^{22,23}$. In case of omphacite, experimental studies on the stability of reaction (1) shows that it is stable in a wide range of pressure-temperature conditions ${ }^{24}$.

\footnotetext{
${ }^{1}$ Department of Earth System Sciences, Yonsei University, Seoul 03722, Republic of Korea. ${ }^{2}$ Geology Division, Korea Institute of Geoscience and Mineral Resources, Daejeon 34132, Republic of Korea. ${ }^{3}$ Department of Geology, Kyungpook National University, Daegu 41566, Republic of Korea. ${ }^{4}$ Department of Earth and Environmental Sciences, Chonnam National University, Gwangju 61186, Republic of Korea. ${ }^{5}$ School of Earth Sciences and Resources, China University of Geosciences Beijing, 29 Xueyuan Road, Beijing 100083, China. ${ }^{6}$ Department of Earth Sciences, University of Adelaide, Adelaide, SA, Australia. ${ }^{\circledR}$ email: vosamuel@gmail.com
} 
The equilibrium reaction satisfies the eclogite definition (Pressure $>1.2 \mathrm{GPa}$ ), if $\mathrm{X}_{\mathrm{Jd}}$ varies from $0.2-0.8$ from $500-900{ }^{\circ} \mathrm{C}^{24}$.

$$
\mathrm{NaAl}_{1} \mathrm{Si}_{2} \mathrm{O}_{6}+\mathrm{SiO}_{2}=\mathrm{NaAl} \mathrm{Si}_{3} \mathrm{O}_{8}
$$

The above results imply that there exists a large variability in composition of garnet and omphacite, while defining a mafic metamorphic rock as the eclogite. Therefore, in many cases a rock with relict almandine and omphacite $\left(\mathrm{X}_{\mathrm{Jd}} 0.2-0.3\right)$, deprived of any other high-pressure metamorphic evidence, are commonly considered as the retrogressed eclogite ${ }^{1-3,25,26}$, and are considered very important in exploring the geodynamic evolution of the deep crust of our planet ${ }^{27,28}$. However, such commonly assumed equilibrium considerations can lead to misinterpretation of crustal evolution of both subducting and overriding plates during subduction-accretioncollision processes.

For the first time, based on the textural evidence, mineral chemistry, and phase diagram modeling, we have provided an excellent natural example of eclogite resembling disequilibrium garnet-omphacite-bearing mafic metamorphic rock, which might have formed under amphibolite to granulite facies $\mathrm{P}-\mathrm{T}$ conditions due to fluidrock interactions. Since Earth's crust is always exposed to fluid-induced alterations during tectonic events ${ }^{29,30}$, formation of disequilibrium garnet-omphacite-bearing amphibolites in the present cases alert that use of the term eclogite based on garnet and omphacite assemblage alone requires caution to discuss their geodynamic interpretation.

Amphibolized mafic metamorphic rocks from the central western Korean Peninsula. We have explored metamorphic history of a Neoproterozoic mafic rock exposed along the central western Korean Peninsula of the southwestern Gyeonggi massif in the Hongseong area (Extended data Fig. 1a) as part of the Hongseong-Imjingang belt, also reported as the Gyeonggi marginal belt ${ }^{31-34}$, as a major Phanerozoic orogenic belt of Korea. In this region, multiple generations of Neoproterozoic, Paleozoic and Middle Triassic dismembered mafic-ultramafic rocks intruded into the Paleoproterozoic basement gneisses, and were metamorphosed during Permo-Triassic in age ${ }^{35-38}$. The Neoproterozoic mafic rocks are exposed in the Bibong, Sinri, and Nunggeum areas in Hongseong area ${ }^{35}$ (Extended data Fig. 1b). Mafic rocks in all three locations above have basaltic/gabbroic composition $^{35}$, and are largely amphibolized with minor garnet and clinopyroxene bearing local pockets/ domains ${ }^{37}$. Presence of omphacite was reported only from the mafic rocks in the Bibong area ${ }^{26,36,37,39}$. Thus, in this study, we have focused mainly on the metamorphosed mafic rocks in the Bibong area of the HongseongImjingang belt (Extended data Fig. 1b).

Previous zircon $\mathrm{U}-\mathrm{Pb}$ geochronology on this mafic rock yielded Neoproterozoic protolith age of $c a$. $803 \pm 24 \mathrm{Ma}$, and middle to upper Triassic metamorphic age of $c a .240$ to $230 \mathrm{Ma}^{35}$. The Sm-Nd whole rockgarnet internal isochron ages from this rock are $258 \pm 11 \mathrm{Ma}$ and $225 \pm 6.6 \mathrm{Ma}^{36}$. The previous geochemical studies using bulk major, trace and REE data shows that the magma source of this rocks is E-MORB-type fertile asthenospheric mantle affected by crustal contamination in a forearc setting during Neoproterozoic subduction event $^{35}$. Subsequently in Permo-Triassic, high-grade metamorphism led to the formation of garnet, omphacite, clinopyroxene assemblage in this rock ${ }^{26,36,37,39}$.

The Bibong outcrops are enclosed within the amphibolite facies Paleoproterozoic and Middle Paleozoic felsic gneisses without any obvious boundary or shear zones ${ }^{36}$ (Extended data Fig. 1b). Except this small body, no other eclogite were found in the Korean Peninsula, and the various amphibolite facies meta-igneous rocks including serpentinized ultramafic rocks, metavolcanics, metasyenite, amphibolite, and amphibole schist also occur as isolated bodies within the basement gneisses ${ }^{35}$. This difference in metamorphic grade with surrounding amphibolite faces basement gneisses were an enigma in interpreting the geology of the western Korean Peninsula. Our field observations show that the lenticular/oval shaped outcrop with a size of $500 \mathrm{~m} \times 200 \mathrm{~m}$ is mostly amphibolized (>90\%), and made up of the dark greenish amphiboles. Within the amphibolized outcrop (Extended data Fig. 2a) there are local high-grade metamorphic domains/pockets bearing feldspar, garnet and clinopyroxene $(<10 \%)$. White feldspar-rich veins occur along the fractures, ranging in width from $\mathrm{mm}$ to a few $\mathrm{cm}$ in thickness (Extended data Fig. 2b-d). We collected samples of the mafic rock with and without garnet, clinopyroxene and feldspar for detailed microstructural study.

Details of microstructural observations. Detailed microstructural relations were studied using three representative thin-sections from the amphibole-enriched part (TS1), domain enriched in amphibole, garnet, diopside and plagioclase (TS2), and omphacite-bearing domain (TS3).

The TS1 is densely packed with dark greenish amphibole laths ranging in size from $\sim 2$ to $5 \mathrm{~mm}$. The grain boundaries are sharp without any reaction textures. Occasionally, discrete minor plagioclase, biotite and ilmenite are present in the matrix. The TS2 and TS3 samples consist mostly of similar $\sim 2$ to $5 \mathrm{~mm}$ size laths of dark greenish to brownish amphiboles. Compositionally they are magnesio-hornblende to magnesio-ferri-hornblende in TS2 and pargasite to ferro-pargasite in $\mathrm{TS}^{40}$ (Extended data Table S1). Locally, these are intensely fractured and are breaking down to form symplectitic textures along grain boundaries (Fig. 1). The main minerals observed in the symplectites are diopside (Extended data Table S2), garnet (56-57\% almandine, 25-27\% grossular and only 15-16\% pyrope content; Extended data Table S3), and plagioclase that has andesine-oligoclase composition (Extended data Table S4; Fig. 1a-f). In back-scattered electron (BSE) image, the diopside shows oval-shaped distinct grains or interconnected grains $(0.2$ to $0.5 \mathrm{~mm})$ with clear polyhedral boundaries (Fig. 1a,b). The mineral is pristine, undeformed and unfractured without any later overprinting of any other minerals around or within them (Fig. 1a-c). In another area, garnet grains along with plagioclase are formed from amphiboles (Fig. 1c). Compared to diopside, rounded to sub-rounded garnet grains are large in size (1 to $2 \mathrm{~mm}$ ). Such garnet-plagioclase assemblage transforms to diopside-plagioclase symplectite further away from amphiboles 

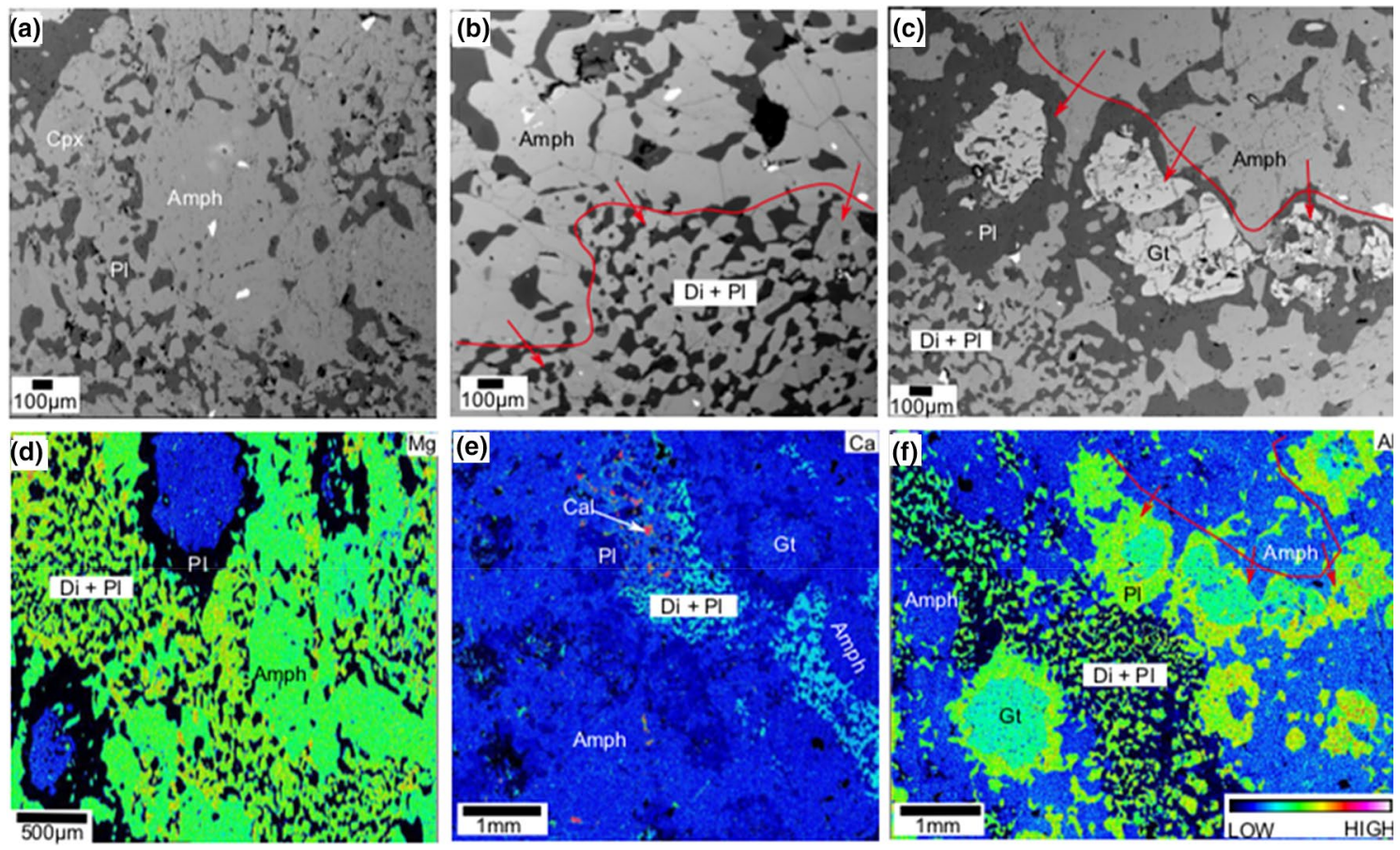

Figure 1. Back-Scattered Electron (BSE) images and elemental maps showing textures of amphibole reaction rims in local domains within TS2 and TS3 thin-sections. (a) Diopside-plagioclase symplectites on the amphibole grain boundaries. (b) Red boundary separates amphibole from symplectite. Red arrows show direction of symplectite formation from amphibole. (c) Garnet grains along with plagioclase formed by amphibole breakdown. Red boundary separates amphibole from symplectite. Red arrows show direction of symplectite formation from amphibole. (d) Mg composition map showing amphibole reaction rims with high-Mg content in diopside. (e) Ca composition map shows amphibole breakdown textures, here calcite grains appears red due to high Ca content. (f) $\mathrm{Al}$ composition map shows amphibole breakdown textures, here plagioclase appears green due to high Al content. Di-diopside; Gt-garnet; Pl-Plagioclase (Andesine-Oligoclase); Amph-Amphibole; Low and High represents color with respect to concentration of elements.

(Fig. 1c). Fully grown garnets have fractures filled with plagioclase (Fig. 1c). Occasionally diopside/amphibole is present within garnet (details of the textures are given in following sections). Compositional maps of $\mathrm{Mg}, \mathrm{Ca}$ and $\mathrm{Al}$ clearly show textures, representing breaking down of large amphibole laths to symplectites along their boundaries (Fig. 1d-f). The microstructural relationships in these samples suggest that amphiboles are breaking down to form garnet-plagioclase, diopside-plagioclase symplectites.

Further microstructural observations show that albite (dark; Extended data Table S5), andesine-oligoclase (grey), diopside (bright) and white calcite are precipitated as veins along fractures in amphibole laths (Fig. 2a). Diopside is precipitated as vein within fracture inside amphibole and albite is precipitated as vein when the fracture extends through andesine-oligoclase (Fig. 2b). Thin albite networks formed along grain boundaries of the andesine-oligoclase matrix outside amphibole laths (Fig. 2c). Garnet, diopside, scapolite (meionite-Extended data Table S6) and ilmenite are also formed in the same areas (Fig. 2c,d), and large calcite grains (Extended data Table S7) are precipitated near garnet, plagioclase, diopside symplectite region (Figs. 1e, 2d).

Different stages of garnet formation, with respect to grain size, are identified in different domains of the TS3 and TS2 thin-sections (Fig. 3a-d). Initial stage is represented by small anhedral garnet crystals formed along the amphibole grain boundaries (Fig. 3a). Larger garnet grains near the amphibole boundaries could be considered as representing the second stage of garnet growth (Fig. 3b). Stage 3 is represented by relict amphibole grains enclosed by growing garnet grains (Fig. 3c). This accounts for the occurrence of amphibole inclusions in the garnet grains during their growth. The final stage is represented by the breakdown of amphibole inclusions within garnet (Fig. 3d). Here, near to albite veins across garnet, amphibole breakdowns to symplectites. Diopsideoligoclase and omphacite (Extended data Table S8)-albite symplectites might have formed during decomposition of amphibole inclusions in garnet.

Elemental compositional maps show more details of breaking down of amphibole inclusions in garnet (Fig. 3e-h). Compositional variations in $\mathrm{Ca}$ (Fig. 3e), $\mathrm{Na}$ (Fig. 3f), $\mathrm{Al}$ (Fig. 3g) and $\mathrm{X}_{\mathrm{Mg}}$ (Fig. 3h) are shown in the maps. Here the albite vein and albite grains have direct contact with omphacite (Fig. $3 \mathrm{~d}, \mathrm{f})$. A healed fracture running through center of the omphacite grain is shown in Fig. 3f. Relicts of previous amphibole inclusions are still present in this domain. The diopside-oligoclase symplectite has comparatively larger grain size than the omphacite-albite assemblage. The omphacite-albite assemblage has a sieve or mesh-like texture, where omphacite appears like a network with dispersed albite grains. They occur adjacent to albite-bearing vein in the fracture within garnet. 

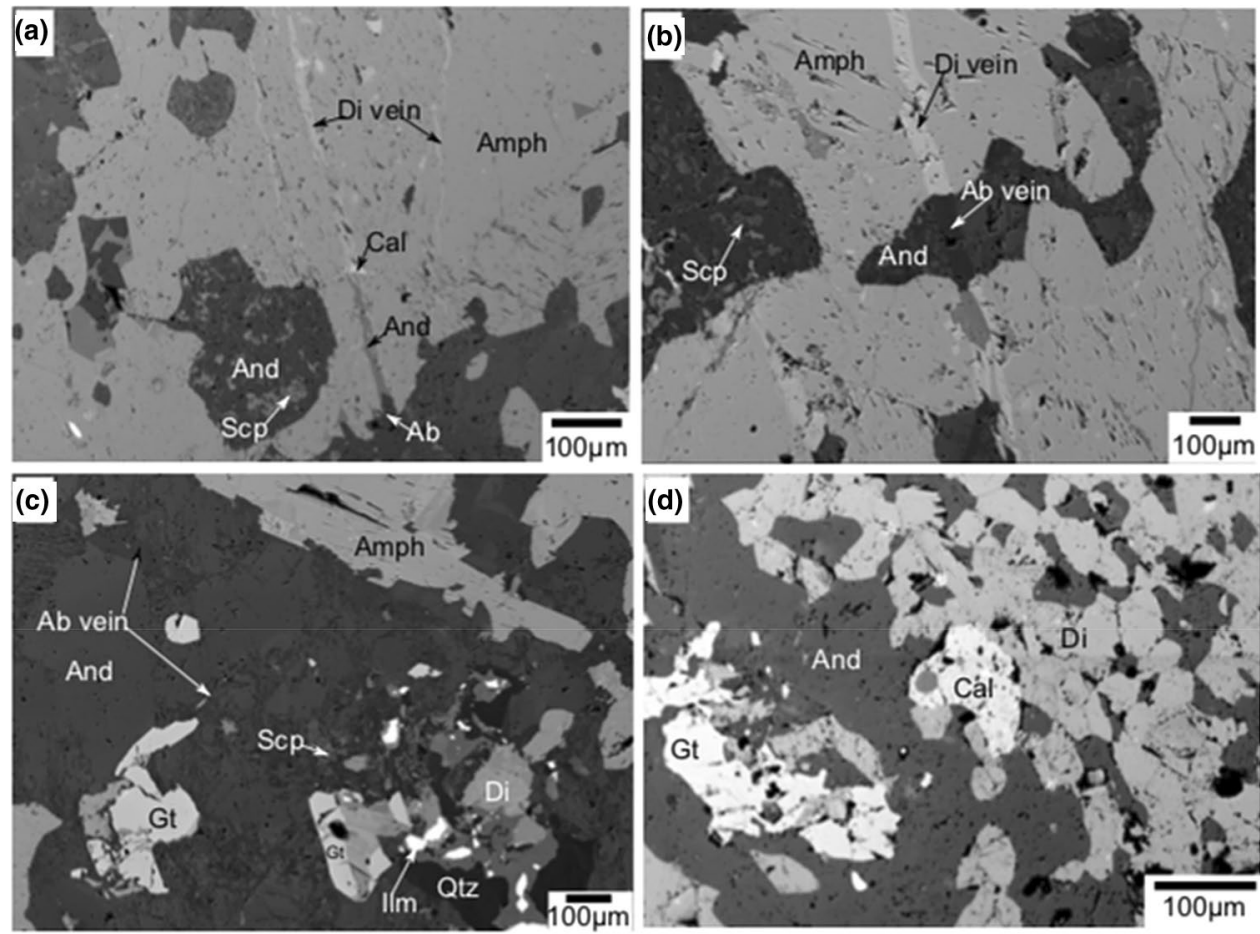

Figure 2. Back-Scattered Electron (BSE) images showing microstructures in TS2 and TS3 samples. (a) Minerals such as albite (dark), andesine (grey), diopside (bright) and white calcite precipitate as veins in fractures. (b) Albite (dark), andesine (grey), diopside (bright) precipitate as veins in fractures that cross-cut the amphibole boundaries. (c) Albite networks forms along grain boundaries of the andesine along with garnet, diopside, scapolite and ilmenite around amphibole boundary. (d) A large calcite grains are precipitated near garnet, plagioclase, diopside symplectite region. Di-diopside; Gt-garnet; And-andesine; Ab-albite; Amph-Amphibole; Scp-scapolite; Cal-calcite.
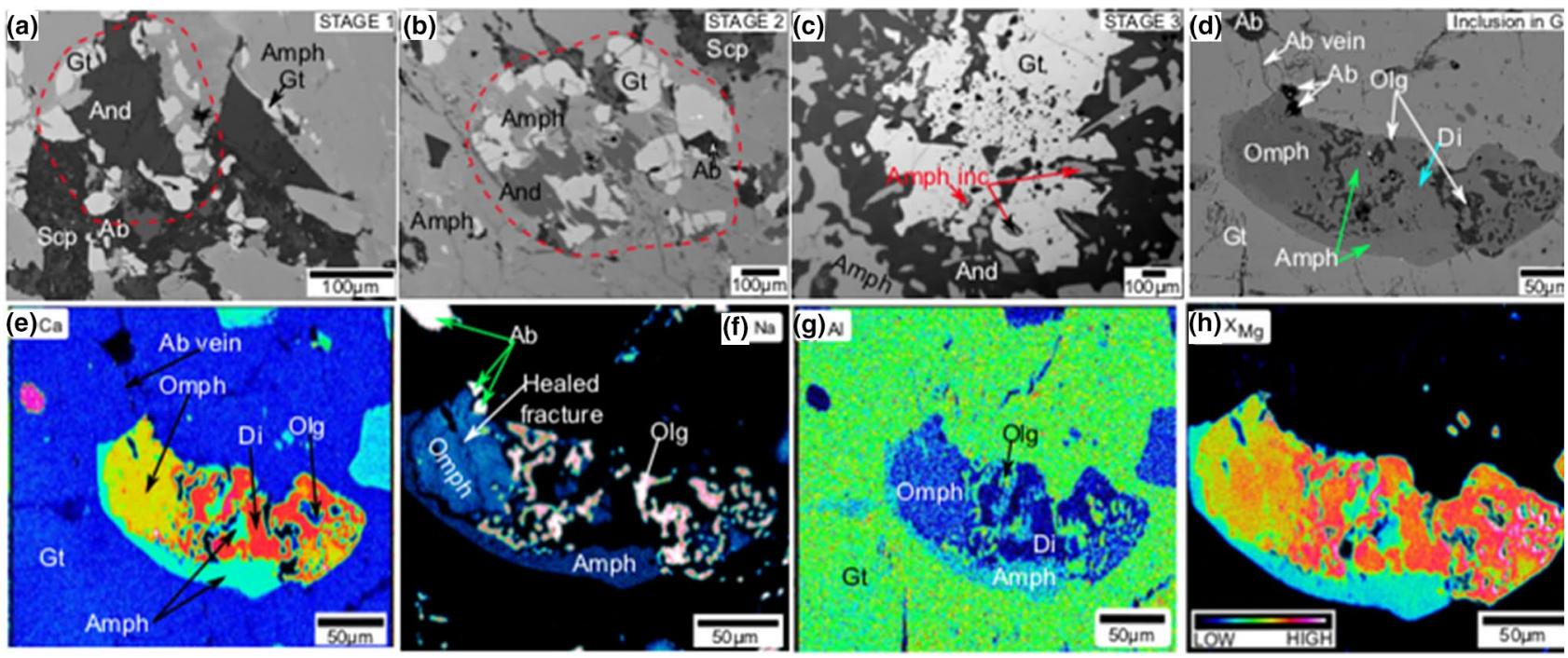

Figure 3. Different stages of garnet formation in the different domains of TS 2 and TS 3 thin-sections. (a) Anhedral garnet crystals formed along the amphibole grain boundaries. (b) Larger garnet grains along with andesine on amphibole boundaries. (c) Relict amphibole grain is getting enclosed by growing garnets. (d) Breakdown of amphibole inclusions within garnet. (e-h) Elemental compositional maps show more details of breaking down of amphibole inclusions in garnet. Compositional variations in $\mathrm{Ca}(\mathbf{e}), \mathrm{Na}(\mathbf{f}), \mathrm{Al}(\mathbf{g})$ and $\mathrm{X}_{\mathrm{Ms}}$ (h) are shown in the maps. High-Ca, low-Al represents diopside. Albite can be identified by high $\mathrm{Na}$, high $\mathrm{Al}$ and absence of $\mathrm{Mg}$. Omphacite has high-Ca, high-Na, low-Al, high-Mg compared to those of amphibole. Di-diopside; Gt-garnet; And-andesine; Olg-oligoclase; Ab-albite; Amph-Amphibole; Omph-omphacite; Scpscapolite. 

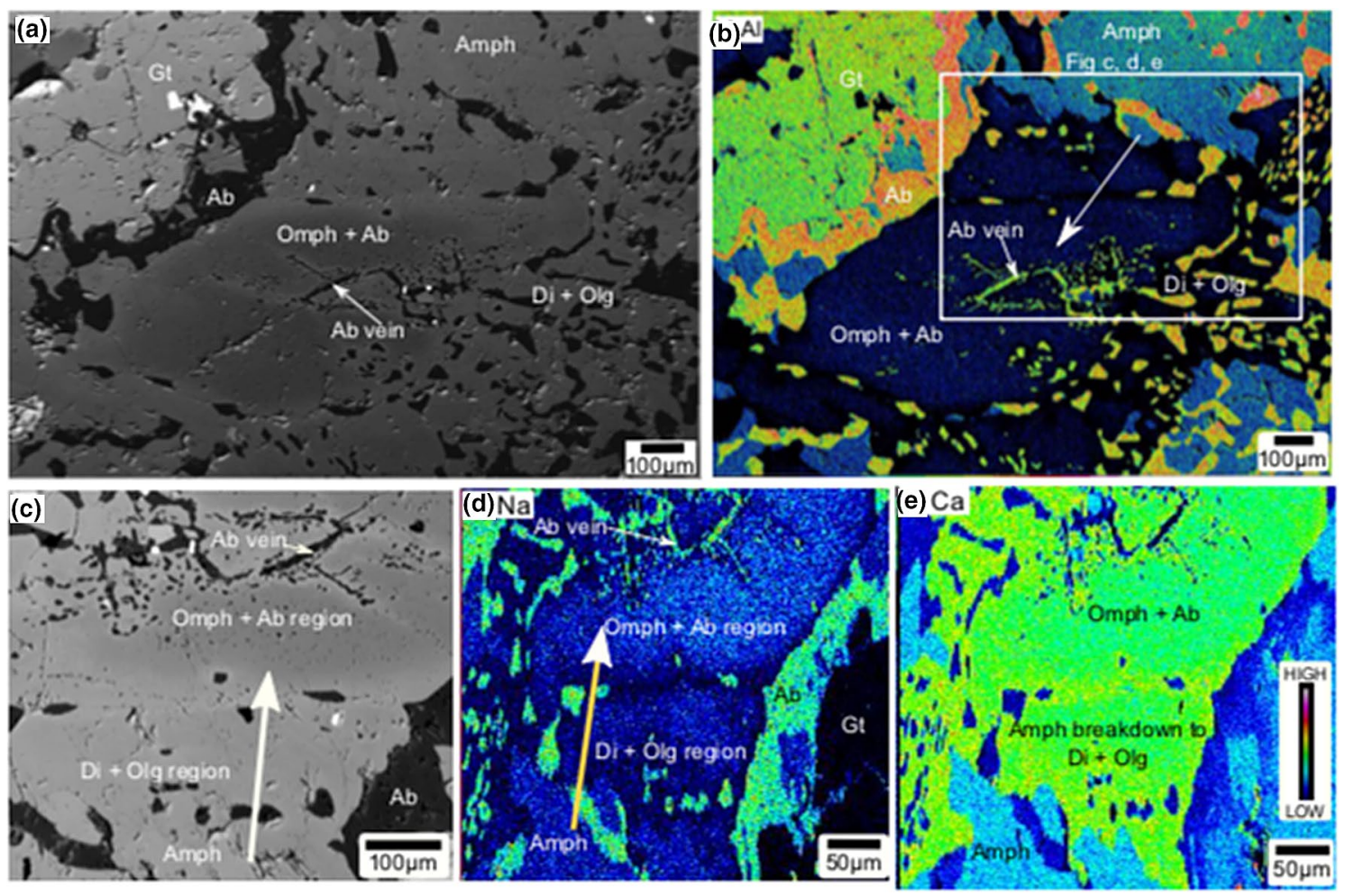

Figure 4. (a,c) Amphibole breaking down to symplectites of diopside-oligoclase and omphacite-albite. Diopside-oligoclase near the amphibole grain boundary transforms to omphacite-albite symplectite near the albite in vein-filled fracture. In this alteration zone the area with omphacite-albite symplectite appears darker in a BSE image due to finer albite grains. (b) Al map shows low-Al content in the pyroxene, moderately high $\mathrm{Al}$ content in the amphibole compared diopside, high-Al content in garnet, very high-Al content in oligoclase and albite. (d) Na map clearly shows the sieve texture of albite and omphacite. (e) Ca map shows high Ca content in amphibole compared to pyroxenes and plagioclase. Diopside has a relatively higher content in Ca compared to omphacite. Di-diopside; Gt-garnet; Olg-oligoclase; Ab-albite; Amph-Amphibole; Omph-omphacite.

Symplectites of diopside-oligoclase and omphacite-albite also occur outside the garnet grains (Fig. 4). Here, omphacite appears to be forming in a pervasive manner around albite-bearing vein (Fig. 4a). Al compositional map shows that omphacite formation occurs where amphibole breaks down to diopside-oligoclase symplectite near the amphibole grain boundary (Fig. 4b). Omphacite-albite symplectite is present further away from the amphibole, adjacent to albite precipitated in vein-filled fractures. Similar to the textures observed in garnet, the omphacite-albite symplectite shows sieve or mesh texture consisting of omphacite and a network of dispersed minute albite grains (Fig. 4c). In this alteration zone, the area with omphacite-albite symplectite appears darker in the BSE image due to finer albite grains (Fig. 4c). The albite phases in the albite-omphacite symplectite become larger near albite veins. The sieve texture of albite and omphacite is obvious in the Na, Ca, Al maps (Fig. 4b-d).

Our detailed petrographic studies show that amphibole, plagioclase (andesine-albite), garnet, clinopyroxene (diopside-omphacite), scapolite (meionite) and calcite are the main mineral assemblage in the metamorphosed mafic rocks from this study. Textural relations show that amphibole laths have broken down to form garnet(andesine-oligoclase), diopside-(andesine-oligoclase), omphacite-albite assemblages along with scapolite and calcite in the localized areas and within garnets. Sub-micron scale disequilibrium omphacite-albite symplectite forms rarely near thick albite bearing veins. Please see "Extended text 1" for the detailed mineral chemistry description.

Phase diagram modeling and pressure (P)-temperature $(T)$ path. Our petrography results show that amphibole is breaking down during the peak metamorphic conditions, where garnet, diopside, plagioclase (andesine-oligoclase) assemblage is present along with scapolite and calcite, and are in textural equilibrium. Presence of calcite (Figs. 1e and 2d) and $\mathrm{CO}_{2}$ bearing scapolite (meionite; Figs. 2 and 3) allows us to consider an open $\mathrm{CO}_{2}$ saturated system. In an open system environment, a fluid which is out of equilibrium first causes some dissolution of a few monolayers of amphibole (parent) phase and makes the fluid supersaturated with respect to a more stable phases ${ }^{41}$. Such amphibole dissolution along with additional Si and Al components in fluids might provide adequate material to form new minerals during open system metasomatism. In our sample, stable new equilibrium phases formed during metasomatism are garnet, diopside, plagioclase (andesine-oligoclase), calcite and scapolite (Fig. 2b). In our sample, $\mathrm{X}_{\mathrm{Mg}}$ of garnet varies from 0.17 to 0.23 , while $\mathrm{X}_{\mathrm{Mg}}$ of diopside varies from 0.58 to 0.67 (Extended data Tables S2, S3). The phase diagram result, along with the isopleths of garnet and clinopyroxene, shows that garnet, diopside, plagioclase (andesine-oligoclase), calcite, scapolite and ilmenite/ rutile assemblage is stable at temperature $\sim 700^{\circ} \mathrm{C}$ and pressure $\sim 0.95 \mathrm{GPa}$ (Fig. 5a). Scapolite, appears as scat- 
(a) $\mathrm{SiO}_{2} ; \mathrm{TiO}_{2} ; \mathrm{Al}_{2} \mathrm{O}_{3} ; \mathrm{FeO} ; \mathrm{MgO} ; \mathrm{CaO} ; \mathrm{Na}_{2} \mathrm{O}$

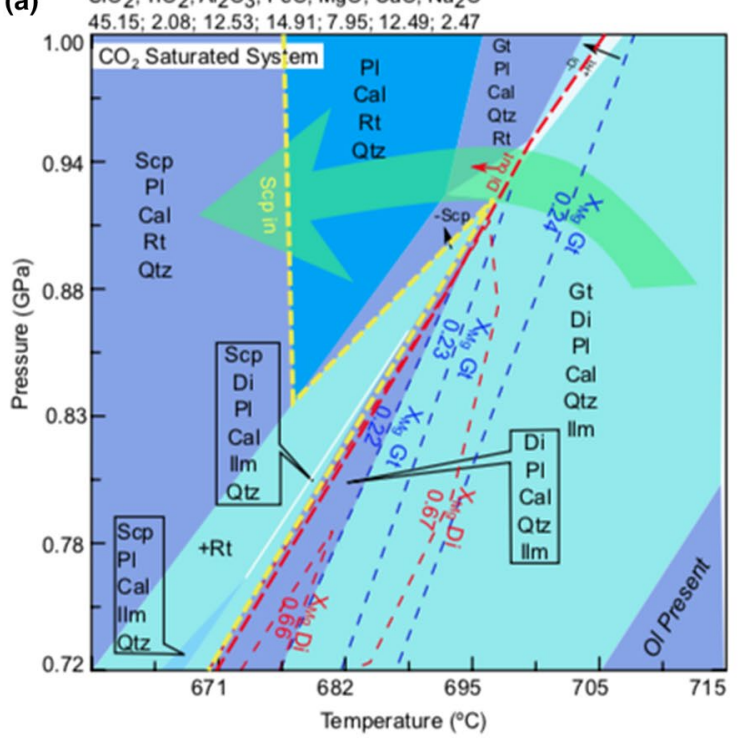

(b)

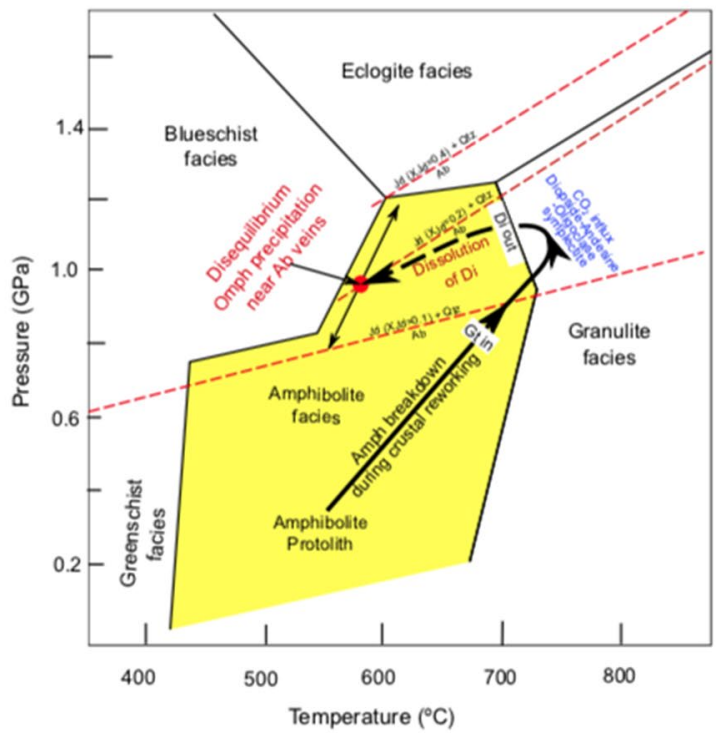

Figure 5. (a) A phase diagram created using Perple_X software 6.7.9 version (inbuilt thermodynamic data fil $^{60}$ ) available at http://www.perplex.ethz.ch ${ }^{59}$, and the published Bulk chemistry data of the Bibong amphibolite ${ }^{37}$. The bulk chemistry data (in wt\%) is given above the phase diagram. Light green arrow shows stability of scapolite during cooling. (b) Phase diagram showing different metamorphic facies conditions ${ }^{42}$ and reaction-1 stability lines ${ }^{24}$ from experimental studies (red lines). The anti-clockwise arrow represents the possible P-T path followed by the amphibolite sample in this study. Di-diopside; Gt-garnet; Pl-plagioclase (andesine-oligoclase); Ab-albite; Jd-jadeite; Qtz-quartz; Cal-calcite; Omph-omphacite; Ilm-Ilmenite; Ol-olivine; Scp-scapolite; Rt-rutile.

tered sub-micron scale grains in the andesine-oligoclase matrix, is stable towards the cooling direction in the phase diagram.

Albite mainly occurs as thin networks along grain boundaries of andesine-oligoclase matrix and as vein-filling in fractured amphiboles and garnets are texturally in disequilibrium with other phases. Pervasive omphacite formation around albite veins indicate that they too are in disequilibrium with other phases. However immediate association of omphacite and albite indicate that they both are in textural equilibrium at least on $1 \mathrm{~mm}$ (milli-meter) scale (Figs. 3d,f, and 4a). This allows us to compare reaction-1 stability lines ${ }^{24}$ from experimental studies with observed P-T conditions. We overlie our phase diagram results and reaction 1 stability lines on published metamorphic facies diagram ${ }^{42}$ (Fig. 5b). The formation of omphacite replacing diopside by disequilibrium coupled dissolution precipitation reactions indicate that diopside was not stable during fluid interaction at lower temperatures. Thus, diopside dissolution occurs at lower temperature. Also, ubiquitous presence of plagioclase represent that the rock is not transformed to eclogite facies, where plagioclase is not stable. In our sample omphacite $\mathrm{X}_{\mathrm{Jd}}$ content varies from 0.9 to 0.3 . Based on above criteria's a milli-meter length scale albiteomphacite precipitation could have occurred during cooling, where diopside-oligoclase becomes unstable. In $\mathrm{mm}$ length scale the reactive fluid enriched in Na could dissolve the unstable parent diopside-oligoclase to form omphacite-albite assemblage. These observations define an anti-clockwise $P-T$ path during the formation of the observed mineral assemblages (Fig. 5b).

Formation of disequilibrium garnet-omphacite assemblage in amphibolite facies. The metamorphosed mafic outcrop in this study is mostly composed of amphiboles $(>90 \%)$ with local areas $(<10 \%)$ carrying higher-grade minerals as symplectites and veins in fractures. Thin-sections from these domains show amphibole breaking down to form garnet-plagioclase (oligoclase-andesine), diopside- plagioclase (oligoclaseandesine) (Figs. 1, 2, 3, 4). Occasional omphacite-albite assemblages replaced diopside-oligoclase near thick albite veins (Figs. 3, 4). The newly formed minerals have no secondary amphiboles formed on their boundaries. The above observations show that the studied rock samples were completely amphibolized prior to the formation of new minerals during metamorphism.

Experimental studies and natural examples both suggest that symplectites could from by the interaction of primary mineral boundaries with reactive fluids ${ }^{43,44}$. We have observed that, minerals such as albite, andesine, calcite and diopside are precipitated along fractures cutting across the amphiboles (Fig. 2a). The vein-filled fractures have albite in composition when they pass through andesine in between the amphibole grains (Fig. 2b). Furthermore, we have noted that albite or andesine-oligoclase is precipitated as vein-fillings in fractures in garnets as well. These observations suggest that, mobile fluids could induce fracturing and generate porosity to allow rapid material transport during metasomatic dissolution-precipitation process ${ }^{45}$. Intense fracturing and precipitation of new minerals as veins in fractures in garnets and amphiboles indicate that fluid induced fracturing and mineral precipitation occurred after garnet-amphibolite to granulite facies conditions. The $258 \pm 11 \mathrm{Ma}$ 
and $225 \pm 6.6 \mathrm{Ma} \mathrm{Sm}-\mathrm{Nd}$ whole rock-garnet internal isochron ages from this rock confirm that garnets might have formed during the Permo-Triassic metamorphic event ${ }^{26,36,37,39}$.

The fluids that caused the alterations or mineral precipitation could act as agents of metasomatism ${ }^{41,45}$. The carrier fluids have imposed coupled dissolution-reprecipitation reactions in the rock and left the system. The mineral assemblage formed during such process could be used to trace back the fluid composition ${ }^{46}$. Amphibole undergoes dissolution to form anhydrous diopside in presence of hot low $-\mathrm{H}_{2} \mathrm{O}$ activity fluids ${ }^{47}$. Calcite and meionite near the thin albite networks in andesine-oligocene matrix in the symplectitic region and as veins in fractures indicate that the system is saturated with $\mathrm{CO}_{2}$ fluid (Fig. 2c,d). Dissolution-precipitation reactions caused by $\mathrm{CO}_{2}$ fluids could have precipitated the sequence of minerals as vein-filled fractures.

It is important to evaluate the conditions during omphacite is precipitated during metamorphism. The omphacite-albite symplectite has a sieve-like texture, where omphacite appears like a network with dispersed sub-micron size albite grains in them. They occur adjacent to the albite bearing vein-filled fractures. The transition from diopside-oligoclase to omphacite-albite in this region occurs gradually, as we can see from the variation of jadeite in clinopyroxene from $9.5 \%$ to maximum $30 \%$ (Fig. 4; Extended data Table S8) and $\mathrm{X}_{\mathrm{An}}$ content in plagioclase from 0.22 to 0.05 (Fig. 4; Extended data Table S5). Such gradual variation in elemental concentration during mineral transformation indicates fluid interfaces, where the fluids selectively dissolve unstable minerals and reprecipitate new ones ${ }^{41,45,48,49}$. Experimental results shows that calcic plagioclase is replaced by albite in aqueous solutions at $600{ }^{\circ} \mathrm{C}$ within weeks, where parent plagioclase and product albite are out of equilibrium ${ }^{50}$. Therefore, such gradual variations might represent a coupled dissolution-reprecipitation reaction, where $\mathrm{CO}_{2}$ fluids preferentially, in a mm length scale, dissolved diopside-plagioclase symplectite, and the resultant fluid produced the omphacite-albite phases (also see pseudosection chapter above).

Comparing textural and mineral chemistry results with pseudosection output, we infer that the rock went through garnet-amphibolite facies condition initially. At this stage, influx of $\mathrm{CO}_{2}$ fluid induced fractures in the earlier formed minerals such as amphibole and garnet. Subsequently, in those fractures, new minerals will precipitate as veins, and also develop symplectites. However, omphacite formation, by replacing diopside, near albite veins does not observed everywhere. Fluids rich in dissolved in Na could have migrated to low stress regions in the outcrop. This is evident from the thin veins of albite (Fig. 2c) in the samples without omphacite and thick veins of albite where diopside dissolution and omphacite formation occurs (Figs. 3d-f, 4). During cooling, the $P-T$ path approached conditions where omphacite-albite assemblage is stable. The maximum jadeite content in the omphacite in our sample is $\sim 30 \%$ (Extended data Table S8). Also garnet in the sample TS3 has $56 \%$ almandine, $27 \%$ grossular and minor $(16 \%)$ pyrope contents, and there is no $\mathrm{X}_{\mathrm{Mg}}$ increase towards its rim (Extended data Fig. 3; Extended data Table S3). There is no other mineralogical evidence in this sample to suggest that the omphacite was formed during high-pressure metamorphism. There are many reports of lowpressure albite-omphacite occurrences in 'garnet-free rocks' as late veins cutting in amphibolites, greenstones, metagraywaekes ${ }^{51,52}$. However, our study shows that below granulite facies conditions, omphacite occurs in disequilibrium with garnet bearing metamorphosed mafic (gabbroic/basaltic) rocks.

During crustal reworking and deformational events, $\mathrm{CO}_{2}$ influx from decarbonation of the nearby or lower crustal carbonate sources induced fractures, and could have produced the observed assemblages in the amphibolite. Symplectitic microstructures could develop in metamorphic rocks during retrogression and/or deformation ${ }^{53}$. Following culmination of the transient fluid activity, the arrested assemblages were exhumed to the surface without further reactions.

Implications of disequilibrium garnet-omphacite in mafic rocks. Conventionally the presence of omphacite in a crustal rock has been correlated with high pressure tectonic environment, especially if garnet is present and is in equilibrium with omphacite. The problem arises when they are present as relict phases where it is difficult to distinguish whether they were formed in equilibrium or disequilibrium. We provide an important example that garnet and omphacite could form in disequilibrium below granulite facies conditions. If such rocks undergo another metamorphic or hydration event there is a possibility that the rock preserve relict garnet and omphacite. Our results alert that textural associations of eclogite resembling assemblages, without any other supporting evidence for high-pressure metamorphism, should be carefully evaluated before defining convergent tectonics including paleo-suture zones and also arriving at conclusions due to diverse situations such as deep subduction and rapid uplift through subduction channel ${ }^{54}$, metasomatic alterations in the deeper parts of the continental crust ${ }^{45}$, cooling of lower crustal mafic granulite through eclogite facies, which could cause foundering of lower mafic crust into mantle ${ }^{55,56}$, and local over-pressuring due to amphibolization or partial melting during crustal reworking/shearing ${ }^{57,58}$. Our study highlights the important role of syn-metamorphic metasomatism in creating disequilibrium assemblages resembling high pressure metamorphism in mafic rocks.

\section{Methods}

Electron microprobe (EPMA). Electron microprobe analyses were conducted on a JEOL JXA-8100 Superprobe, Electron Probe Micro Analyzer (EPMA), housed at the Department of Earth System Sciences, Yonsei University, Seoul, South Korea. Core to rim compositions of important mineral assemblages in TS1, TS2 and TS3 were analyzed. Analytical conditions are accelerating voltage of $20 \mathrm{kV}$; beam current of $20 \mathrm{nA}$; counting time of $10 \mathrm{~s}$ and an electron beam spot size of $5 \mu \mathrm{m}$. Peak position was adjusted to 129.9 for measuring Na content in the omphacite. In the standard position 129.27, $\mathrm{Na}$ content and total composition were low. Similarly, slight adjustment has done to measure $\mathrm{Mg}$ and $\mathrm{Al}$ in garnet, amphibole, diopside and omphacite to obtain maximum count by scanning for peaks before quantitative analysis. Natural and synthetic silicates and oxides supplied by JEOL and ASTIMEX standards Ltd., Canada, were used for calibration. The data were reduced using the ZAF correction procedures supplied by JEOL. 
Phase diagram. Phase diagram modeling using bulk-chemistry of the amphibolite provide a good opportunity to examine the stability of different mineral phases and their compositional changes during the evolution of this particular rock in a pressure temperature space. PERPLE_X 6.7.9 version available at http://www.perpl ex.ethz.ch ${ }^{59}$ and inbuilt thermodynamic data file ${ }^{60}$ were used for phase diagram calculations. Bulk chemistry (in wt $\%)$ of the sample is taken from reference 47 and has $\mathrm{SiO}_{2} ; 45.15 ; \mathrm{TiO}_{2} ; 2.08 ; \mathrm{Al}_{2} \mathrm{O}_{3} ; 12.53 ; \mathrm{FeO} ; 14.91 ; \mathrm{MgO}$; 7.95; $\mathrm{CaO} ; 12.49 ; \mathrm{Na}_{2} \mathrm{O} ; 2.47$. The $\mathrm{MnO}, \mathrm{K}_{2} \mathrm{O}$ and $\mathrm{P}_{2} \mathrm{O}_{5}$ compositions were not considered due to their low concentrations. The following solid-solution models were used for phase diagram calculation: garnet ${ }^{61}(\mathrm{Gt}(\mathrm{W}))$; Diopside $^{62,63}(\mathrm{Cpx}(\mathrm{h}))$; plagioclase ${ }^{64}(\mathrm{Pl}(\mathrm{h}))$; Ilmenite (IlGkPy (ideal)); calcite ${ }^{65}(\mathrm{Cc}(\mathrm{AE}))$; Scapolite $(\mathrm{Scp})$. We have used $\mathrm{CO}_{2}$ activity of 1 and $\mathrm{X}_{\mathrm{CO} 2}$ fluid equation of state ${ }^{60}$. The two-dimensional P-T pseudosection was calculated in a window where temperature changes from 660 to $715^{\circ} \mathrm{C}$ on the $\mathrm{X}$-axis and pressure varies from 0.72 to $1 \mathrm{GPa}$ on the Y-axis.

Received: 9 September 2020; Accepted: 5 November 2020

Published online: 16 November 2020

\section{References}

1. Möller, A., Appel, P., Mezger, K. \& Schenk, V. Evidence for a 2.0 Ga subduction zone: Eclogites in the Usagaran belt of Tanzania. Geology 12, 1067-1070 (1995).

2. Volodichev, O. I., Slabunov, A. I., Bibikova, E. V., Konilov, A. N. \& Kuzenko, T. I. Archean eclogites in the Belomorian mobile belt, Baltic Shield. Petrology 12, 540-560 (2004).

3. Weller, O. \& St-Onge, M. Record of modern-style plate tectonics in the Palaeoproterozoic Trans-Hudson orogen. Nat. Geosci. 10, 305-311 (2017).

4. Cox, R. \& Indares, A. Transformation of Fe-Ti gabbro to coronite, eclogite and amphibolite in the Baie du Nord segment, eastern Grenville Province. J. Metamorph. Geol. 17, 537-555 (1999).

5. Storey, C. D., Brewer, T. S. \& Temperley, S. P-T conditions of Grenville-age eclogite facies metamorphism and amphibolite facies retrogression of the Glenelg-Attadale Inlier, NW Scotland. Geol. Mag. 142, 605-615 (2005).

6. Ernst, W. G., Tsujimori, T., Zhang, R. Y. \& Liou, J. G. Permo-Triassic collision, subduction-zone metamorphism, and tectonic exhumation along the East Asian continental margin. Ann. Rev. Earth Planet. Sci. 35, 73-110 (2007).

7. Willard, R. A. \& Adams, M. G. Newly discovered eclogite in the southern Appalachian orogen, northwestern North Carolina. Earth Planet. Sci. Lett. 123, 61-70 (1994).

8. Katayama, I., Parkinson, C. D., Okamoto, K., Nakajima, Y. \& Maruyama, S. Supersilicic clinopyroxene and silica exsolution in UHPM eclogite and pelitic gneiss from the Kokchetav massif, Kazakhstan. Am. Miner. 85, 1368-1374 (2000).

9. Aoya, M. P-T-D path of eclogite from the Sambagawa belt deduced from combination of petrological and micro- structural analyses. J. Petrol. 42, 1225-1248 (2001).

10. Kurz, W. \& Froitzheim, N. The exhumation of eclogite facies metamorphic rocks: A review of models confronted with examples from the Alps. Int. Geol. Rev. 44, 702-743 (2002).

11. O'Brien, P. J. Eclogites and other high-pressure rocks in the Himalaya: A review. Himal. Tecton. Mod. Synth. 483, 183-213 (2019).

12. Moore, D. E. \& Blake, M. C. New evidence for polyphase metamorphism of glaucophane schist and eclogite exotic blocks in the Franciscan Complex, California and Oregon. J. Metamorph. Geol. 7, 211-228 (1989).

13. Chopin, C. Ultrahigh-pressure metamorphism: Tracing continental crust into the mantle. Earth Planet. Sci. Lett. 212, 1-14 (2003).

14. Hermann, J. \& Rubatto, D. Subduction of continental crust to mantle depth: Geochemistry of ultrahigh-pressure rocks. In Treatise on Geochemistry, Volume 4: The Crust 2nd edn (ed. Rudnick, R. L.) 309-340 (Elsevier, Amsterdam, 2014).

15. Hacker, B. R. \& Liou, J. G. When Continents Collide: Geodynamics and Geochemistry of Ultrahigh-Pressure Rocks (Kluwer Academic, Dordrecht, 1998).

16. Hacker, B. R. et al. U/Pb zircon ages constrain the architecture of the ultrahigh-pressure Quinling-Dabie Orogen, China. Earth Planet. Sci. Lett. 161, 215-230 (1998).

17. Rubatto, D. \& Hermann, J. Exhumation as fast as subduction?. Geology 29, 3-6 (2001).

18. Coleman, R. G., Lee, D. E., Beatty, L. B. \& Brannock, W. W. Eclogites and eclogites. Their differences and similarities. Geol. Soc. Am. Bull. 76, 483-508 (1965).

19. Hacker, B. R. Eclogite formation and rheology, buoyancy, seismicity and $\mathrm{H}_{2} \mathrm{O}$ content of oceanic crust. AGU Geophys. Monogr. 96, 337-346 (1996).

20. Morimoto, N. et al. Nomenclature of pyroxenes. Am. Miner. 73, 1123-1133 (1988).

21. Green, D. H. \& Ringwood, A. E. An experimental investigation of the gabbro-eclogite transformation and its petrological implications. Geochim. Cosmochem. Acta 31, 767-833 (1967).

22. Green, D. H., Lockwood, J. P. \& Kiss, E. Eclogite and almandine-jadeite-quartz rock from the Guajira Peninsula, Colombia, South America. Am. Mineral. 53, 1320-1335 (1968).

23. Oh, C. W., Liou, J. G. \& Maruyama, S. Low-temperature eclogites and eclogitic schists in Mn-rich metabasites in Ward Creek, California; Mn and Fe effects on the transition between blueschist and eclogite. J. Petrol. 32, 275-302 (1991).

24. Holland, T. J. B. The experimental determination of activities in disordered and short-range ordered jadeitic pyroxenes. Contrib. Miner. Petrol. 82, 214-220 (1983).

25. Pilitsyna, A. V. et al. Eclogites and garnet clinopyroxenites in the Anrakhai complex, Central Asian Orogenic Belt, Southern Kazakhstan: P-T evolution, protoliths and some geodynamic implications. J. Asian Earth Sci. 153, 325-345 (2018).

26. Oh, C. W. et al. First finding of eclogite facies metamorphic event in South Korea and its correlation with the Dabie-Sulu collision belt in China. J. Geol. 113, 226-232 (2005).

27. Holder, R. M., Viete, D. R., Brown, M. \& Johnson, T. E. Metamorphism and the evolution of plate tectonics. Nature 572, 378-381 (2019).

28. Stern, R. J. Evidence from ophiolites, blueschists, and ultra-high pressure metamorphic terranes that the modern episode of subduction tectonics began in Neoproterozoic time. Geology 33, 557-560 (2005).

29. Austrheim, H. \& Griffin, W. L. Shear deformation and eclogite formation within granulite facies anorthosites of the Bergen arcs, western Norway. Chem. Geol. 50, 267-281 (1985).

30. Jamtveit, B., Austrheim, H. \& Putnis, A. Disequilibrium metamorphism of stressed lithosphere. Earth Sci. Rev. 154, 1-13 (2016).

31. Kwon, S. et al. Evidence for permo-triassic collision in far east Asia: The Korean collisional orogen. Earth Planet. Sci. Lett. 279, 340-349 (2009).

32. Cho, M. et al. Tectonic evolution of Precambrian basement massifs and an adjoining fold-and-thrust belt (Gyeonggi Marginal Belt), Korea: An overview. Geosci. J. 21, 845-865 (2017). 
33. Kim, S. W. et al. Tracking Paleozoic evolution of the South Korean Peninsula from detrital zircon records: Implications for the tectonic history of East Asia. Gondwana Res. 50, 195-215 (2017).

34. Wang, J., Santosh, M., Li, S. \& Kim, S. W. Magmatic and hydrothermal zircon growth during multiple orogenic cycles in an evolving mantle wedge. Geosci. Front. 10, 439-452 (2019).

35. Kwon, S., Kim, S. W. \& Santosh, M. Multiple generations of mafic-ultramafic rocks from the Hongseong suture zone, western South Korea: Implications for the geodynamic evolution of NE Asia. Lithos 161, 68-83 (2013).

36. Park, S.-I., Kwon, S., Kim, S. W., Yi, K. \& Santosh, M. Continental origin of the Bibong eclogite, southwestern Gyeonggi massif, South Korea. J. Asian Earth Sci. 95, 192-202 (2014).

37. Kim, H. S., Kwon, S., Kim, S. W. \& Santosh, M. Permo-triassic high-pressure metamorphism in the central western Korean peninsula, and its link to Paleo-tethyan ocean closure: Key issues revisited. Geosci. Front. 9, 1325-1335 (2018).

38. Kim, S. W. et al. Detrital zircon U-Pb and Hf isotope characteristics of the Early Neoproterozoic successions in the central-western Korean Peninsula: Implication for the Precambrian tectonic history of East Asia. Precambr. Res. 322, 24-41 (2019).

39. Kim, S. W. et al. Phanerozoic high-pressure eclogite and intermediate pressure granulite facies metamorphism in the Gyeonggi block, South Korea: Implications for the eastward extension of the Dabie-Sulu continental collision zone. Lithos 92, 357-377 (2006).

40. Hawthorne, F. C. et al. Nomenclature of the amphibole supergroup. Am. Miner. 97, 11-12 (2012).

41. Putnis, A. \& Austrheim, H. Fluid-induced processes: Metasomatism and metamorphism. Geofluids 10, 254-269 (2010).

42. Konilov, A. N. et al. The Salma eclogites of the Belomorian province, Russia: HP/UHP metamorphism through the subduction of Mesoarchean oceanic crust. In Ultrahigh-Pressure Metamorphism (eds Dobrzhinetskaya, L. F. et al.) 623-644 (Elsevier, Amsterdam, 2011).

43. Spruzeniece, L., Piazolo, S., Daczko, N. R., Kilburn, M. R. \& Putnis, A. Symplectite formation in the presence of a reactive fluid: Insights from hydrothermal experiments. J. Metamorph. Geol. 35, 281-299 (2017).

44. Daczko, N. R., Stevenson, J. A., Clarke, G. L. \& Klepeis, K. A. Successive hydration and dehydration of high-P mafic granofels involving clinopyroxene-kyanite symplectites, Mt Daniel, Fiordland, New Zealand. J. Metamorph. Geol. 20, 669-682 (2002).

45. Putnis, A. Mineral replacement reactions. Rev. Mineral. Geochem. 70, 87-124 (2009).

46. Austrheim, H. Eclogitization of lower crustal granulites by fluid migration through shear zones. Earth Planet. Sci. Lett. 81, 221-232 (1987).

47. Aranovich, L. Y., Shmulovich, K. I. \& Fedkin, V. V. The $\mathrm{H}_{2} \mathrm{O}$ and $\mathrm{CO}_{2}$ regime in regional metamorphism. Int. Geol. Rev. 29, 1379-1401 (1987).

48. Ferrando, S., Petrelli, M. \& Frezzotti, M. L. Gradual and selective trace-element enrichment in slab-released fluids at sub-arc depths. Sci. Rep. 9, 16393 (2019).

49. Harlov, D. E. \& Austrheim, H. Metasomatism and the Chemical Transformation of Rock (Springer, Berlin, 2012).

50. Hövelmann, J., Putnis, A., Geisler, T., Schmidt, B. C. \& Golla-Schindler, U. The replacement of plagioclase feldspars by albite: Observations from hydrothermal experiments. Contrib. Mineral. Petrol. 159, 43-59 (2010).

51. Essene, E. J. \& Fyfe, W. S. Omphacite in Californian metamorphic rocks. Contrib. Miner. Petrol. 15, 1-23 (1967).

52. Miyazoe, T., Nishiyama, T., Uyeta, K., Miyazaki, K. \& Mori, Y. Coexistence of pyroxenes jadeite, omphacite, and diopside/hedenbergite in an albite omphacite rock from a serpentinite mélange in the kurosegawa zone of central Kyushu, Japan. Am. Mineral. 94, 34-40 (2009).

53. Vernon, R. H. Symplectic intergrowth. In A Practical Guide to Rock Microstructure 242-254 (Cambridge University Press, Cambridge, 2004).

54. Gerya, T. V., Stockert, B. \& Perchuk, A. L. Exhumation of high-pressure rocks in a subduction channel: A numerical simulation. Tectonics 21, 1056 (2002).

55. Ellis, D. J. \& Maboko, M. A. H. Precambrian tectonics and the physio-chemical evolution of the continental crust. I. the gabbroeclogite transition revisited. Precambrian Res. 55, 491-506 (1992).

56. Chapman, T., Clarke, G. L., Piazolo, S. \& Daczko, N. R. Evaluating the importance of metamorphism in the foundering of continental crust. Sci. Rep. 7, 13039 (2017).

57. Chu, X., Ague, J. J., Podladchikov, Y. Y. \& Tian, M. Ultrafast eclogite formation via melting induced overpressure. Earth Planet. Sci. Lett. 479, 1-17 (2017).

58. Putnis, A., Jamtveit, B. \& Austrheim, H. Metamorphic processes and seismicity: The Bergen Arcs as a natural laboratory. J. Petrol. 58, 1871-1898 (2017).

59. Connolly, J. A. D. Computation of phase equilibria by linear programming: A tool for geodynamic modelling and its application to subduction zone decarbonation. Earth Planet. Sci. Lett. 236, 524-541 (2005).

60. Holland, T. J. B. \& Powell, R. An improved and extended internally consistent thermodynamic dataset for phases of petrological interest, involving a new equation of state for solids. J. Metamorph. Geol. 29, 333-383 (2011).

61. White, R. W., Powell, R., Holland, T. J. B., Johnson, T. E. \& Green, E. C. R. New mineral activity-composition relations for thermodynamic calculations in metapelitic systems. J. Metamorph. Geol. 32, 261-286 (2014).

62. Gasparik, T. Experimental study of subsolidus phase relations and mixing properties of pyroxene in the system $\mathrm{CaO}-\mathrm{Al}_{2} \mathrm{O}_{3}-\mathrm{SiO}_{2}$. Geochim. Cosmochim. Acta 48, 37-45 (1984).

63. Gasparik, T. Experimental study of subsolidus phase relations and mixing properties of pyroxene and plagioclase in the system $\mathrm{Na}_{2} \mathrm{O}-\mathrm{CaO}-\mathrm{Al}_{2} \mathrm{O}_{3}-\mathrm{SiO}_{2}$. Contrib. Miner. Petrol. 89, 46-57 (1985).

64. Newton, R. C., Charlu, T. V. \& Kleppa, O. J. Thermochemistry of the high structural state plagioclases. Geochem. Cosmochim. Acta 44, 33-41 (1980).

65. Anovitz, L. \& Essene, E. J. Phase equilibria in the system $\mathrm{CaCO}_{3}-\mathrm{MgCO}_{3}-\mathrm{FeCO}_{3}$. J. Petrol. 28, 389-414 (1987).

\section{Acknowledgements}

This research was supported by 2017R1A6A1A07015374 (Multidisciplinary study for assessment of large earthquake potentials in the Korean Peninsula) through the National Research Foundation of Korea (NRF) funded by the Ministry of Science and ICT, Korea to V.O.S, and NRF-2019R1A2C1002211 to S.K. S.W. Kim appreciate the support by a Basic Research Project (GP2020-003; Geological survey in the Korean Peninsula and publication of the geological maps) of the KIGAM, funded by the Ministry of Science and ICT. We also acknowledge the support by Prof. K. Sajeev for upgrading compositional map in Fig. 3 using EPMA facility at AFMM, IISc, Bangalore, India.

\section{Author contributions}

S.K. and V.O.S., conceived the projects. S.K., S.W.K., V.O.S., Y.J. and S.-I.P., collected the samples. V.O.S., and Y.S., performed EPMA analyses. V.O.S did petrographic, and phase diagram modelling. All authors contributed to data evaluation, interpretation and paper writing. 


\section{Competing interests}

The authors declare no competing interests.

\section{Additional information}

Supplementary information is available for this paper at https://doi.org/10.1038/s41598-020-76999-y.

Correspondence and requests for materials should be addressed to V.O.S.

Reprints and permissions information is available at www.nature.com/reprints.

Publisher's note Springer Nature remains neutral with regard to jurisdictional claims in published maps and institutional affiliations.

Open Access This article is licensed under a Creative Commons Attribution 4.0 International (c) License, which permits use, sharing, adaptation, distribution and reproduction in any medium or format, as long as you give appropriate credit to the original author(s) and the source, provide a link to the Creative Commons licence, and indicate if changes were made. The images or other third party material in this article are included in the article's Creative Commons licence, unless indicated otherwise in a credit line to the material. If material is not included in the article's Creative Commons licence and your intended use is not permitted by statutory regulation or exceeds the permitted use, you will need to obtain permission directly from the copyright holder. To view a copy of this licence, visit http://creativecommons.org/licenses/by/4.0/.

(c) The Author(s) 2020 